\title{
Pengaruh Model Pembelajaran Cooperative Learning Tipe Stad Terhadap Hasil Belajar Pkn Siswa Kelas Iv Sdn Lenggahsari 04 Cabang Bungin Bekasi
}

\author{
Siti Afifah" ${ }^{1}$, "Santhi Pertiwi ${ }^{2)}$ \\ ${ }^{1), 2}$ Program Studi Pendidikan Sekolah Dasar, Fakultas Ilmu Pendidikan dan Keguruan \\ Universitas Mohammad Husni Thamrin
}

Correspondence Author : antique_sp11@yahoo.com, Jakarta-Indonesia.

DOI : https://doi.org/10.37012/jipmht.v5i1.657

Received : 25 Desember 2021

Accepted : 25 Maret 2021

Published: 30 Maret 2021

\begin{abstract}
ABSTRAK
Peneliti melakukan wawancara dengan guru kelas IV SD bahwa metode pembelajaran Pendidikan Kewarganegaraan ( $\mathrm{PKn}$ ) selama ini masih menerapkan model pembelajaran ceramah, dan masih berpusat pada guru, sehingga peserta didik kurang aktif dalam berpartisipasi dan kreatif. Tujuan penelitian ini untuk mengetahui seberapa pengaruh metode pembelajaran kooperatif Student Teams Achievement Division STAD terhadap hasil belajar siswa kelas dalam pembelajaran PKN. Penelitian dilaksanakan di SDN Lenggahsari 04 Cabang Bungin Bekasi, sampel siswa kelas IV pada tahun pembelajaran 2020. Populasi dalam penelitian ini, siswa kelas IV SDN lengahsari 04 cabang Bungin Bekasi, terdiri IV A sebanyak 36 orang siswa dan IV B sebanyak 36 orang siswa. Penelitian ini untuk mengetahui pengaruh metode pembelajaran kooperatif STAD hasil belajar siswa kelas IV dalam pembelajaran PKn. Metode yang digunakan adalah metode eksperimen dengan post-test kontrol grup design digunakan uji-t untuk mengumpulkan data untuk di analisis. Hasil penelitian ini menunjukan bahwa metode pembelajaran kooperatif STAD berpengaruh signitif terhadap hasil belajar siswa kelas IV SD penerima PKN. Dari hasil uji-t dapat disimpulkan bahwa uji-t tersebut membuktikan bahwa t hitung lebih besar dari t tabel jika $\alpha=0,05$ yaitu 2,673 >2,03 dan skor rata - rata hasil belajar siswa di kelas eksperimen lebih tinggi dari pada nilai rata - rata kelas kontrol yaitu 66,08 > 63,5.
\end{abstract}

Kata Kunci: Metode Cooperative Learning tipe STAD, Hasil Belajar, Pembelajaran PKN SD.

\begin{abstract}
The researcher conducted interviews with fourth grade elementary school teachers that the Civic Education (PKn) learning method so far still applies the lecture learning model, and is still teacher-centered, so that students are less active in participating and being creative. The purpose of this study was to determine how much influence the STAD Student Teams Achievement Division cooperative learning method had on student learning outcomes in PKN learning. The research was carried out at SDN Lenggahsari 04 Bungin Bekasi Branch, a sample of grade IV students in the 2020 academic year. The population in this study, grade IV students at SDN Lengahsari 04 Bungin Bekasi branch, consisted of 36 students IV A and 36 students IV B. This study was to determine the effect of the STAD cooperative learning method on the learning outcomes of fourth grade students in Civics learning. The method used is experimental method with post-test control group design used t-test to collect data for analysis. The results of this study indicate that the STAD cooperative learning method has a significant effect on the learning outcomes of fourth grade elementary school students receiving PKN. From the results of the $t$-test, it can be concluded that the $t$-test proves that $t$-count is greater than $t$-table if $=0.05$, i.e. $2.673>2.03$ and the average score of student learning outcomes in the experimental class is higher than the average score. - the average control class is $66.08>63.5$.
\end{abstract}

Keywords: STAD Cooperative Learning Method, Learning Outcomes, PKN SD Learning. 


\section{PENDAHULUAN}

Pendidikan, usaha belajar siswa dalam mencapai tujuan tertentu sehingga usaha belajar siswa dalam mencapai tujuan belajar yakni pengembangan potensi dalam diri siswa. sehingga berguna untuk dirinya dan orang lain. Hal init ercantum dalam undang- undang Republik Indonesia Pasal 3 No 20 tahun 2003 tentang Sistem Pembelajaran Nasional menerangkan: Pembelajaran Nasioanal berperan meningkatkan keahlian serta membentuk sifat dan peradaban bangsa yang bermartabat dalam rangka mencerdaskan kehidupan bangsa. Pembelajaran bertujuan buat meningkatkan kemampuan didik supaya matis serta jadi manusia yang beriman serta bertakwa kepada Tuhan Yang Maha Esa, berakhlak mulia, sehat, berilmu, cakap, kreatif, mandiri, serta bisa jadi masyarakat Negeri yang demokatis serta tanggung jawab"'(Depdiknas, $2003: 4)$.

Pembentukan dalam sikap dan mental, perilaku dan pribadi anak didik, guru harus lebih hati-hati dalam pendekatan. Maka dari itu diperlukannya pengarahan motivasi dan berfikir dengan menggunakan cara guru sendiri melalui berbagai contoh. Keterampilan dapat di didik dengan cara melatih kemampuan agar mendapatkan hasil belajar yang baik. Dalam dunia pendidikan Guru wajib meningkatkan pengalaman belajar siswa untuk mencapai tujuan pembelajaran PKN ( Pendidikan Kewarganegaraan ). Dimana ilmu itu mempelajari sikap kepahlawanan, Pembelajaran PKN merupakan keaktifan antara siswa dan lingkungan sekitarnya. Hal ini yang mengakibatkan pembelajaran PKN perlu adanya peran siswa dalam kegiatan belajar dan pembelajaran. Oleh karena itu, pembelajaran PKN perlu menerapkan prinsip - prinsip pembelajaran yang tepat sehingga pencapaian hasil yang diperoleh siswa dapat tercapai secara maksimal. PKN juga membahas tentang Sikap Kepahlawanan. Pahlawan adalah pejuang yang gagah berani serta rela berkorban membela tanah air dengan tanpa pamrih tidak bergantungan dengan siapapun dan mempunya tanggung jawab sangat tinggi dalam mempertahankan dan martabat bangsa. Sifat seperti itulah yang sangat diperlukan bagi para generasi muda untuk menghadapi penjajahan arus globalisasi dan kapitalisme di Indonesia saat ini. Dampak nya budaya pada budaya - budaya baru yang tentu perlunya adanya antisipasi pada diri kaum muda, agar tidak terjerumus pada budaya budaya yang menghilangkan karakter bangsa.

Berdasarkan hal tersebut, masyarakat Indonesia setiap tanggal 10 November memperingati hari pahlawan. Sikap kepahlawanan yang dimiliki pahlawan terdahulu perlu ditanamkan sejak dini pada anak-anak agar kelak jadi orang yang berguna bagi sesama, keluarga, dan negara. Pembalajaran PKN tingkat sekolah dasar tujuan nya untuk menciptakan potensi 
individu, berupa sikap kepribadian seseorang ditunjukan dari tanggung jawab individu dalam berbagai kehidupan masyarakat berbangsa dan bernegara yang ditanamkan sejak dini. Guru yang mengajarkan pembelajaran PKN biasanya menggunakan metode ceramah yang menjelaskan teori sehingga membuat siswa jenuh dan kurang menarik perhatian, guru menjadi sentral informasi, sedangkan siswa menjadi penerima informasi sehingga siswa hanya menyerap beberapa persen informasi yang disampaikan guru jika hal ini terus menerus terjadi maka menjadikan hasil belajar siswa rendah.

Hasil belajar berkaitan dengan kemampuan berpikir kritis dan ilmiah pada siswa sekolah dasar. Berkaitan dengan faktor-faktor yang mempengaruhi hasil belajar, Ngalim Purwanto pendapat bahwa faktor- faktor yang dapat mempengaruhi proses hasil belajar (Susanto 2013, 138) mengemukakan faktor mempengaruhi yaitu lingkungan, berupa lingkungan alam dan sosial, instrumental yang dirancang atau dimanupulasi, fisiologi kondisi fisiknya, panca inderanya, dan sebagainya, psikologi minat, bakat, kecerdasan, motivasi, dan kemampuan kognitif.

Dengan model pendidikan jenis STAD STAD (Student Teams Achievement Division) ini, diharapkan atmosfer pendidikan PKN yang biasanya memunculkan rasa bosan jadi atmosfer yang mengasyikkan sehingga memotivasi serta hasil belajar siswa bisa bertambah. Salah satu antara lain modul PKN yang dalam penyampaiannya bisa memakai model pendidikan Kooperatif jenis STAD (Student Teams Achievement Division) merupakan modul Perilaku Kepahlawanan. Model pendidikan jenis STAD (Student Teams Achievement Division) ini, diharapkan atmosfer pendidikan PKN yang biasanya memunculkan rasa bosan jadi atmosfer yang mengasikan sehingga memotivasi serta hasil belajar siswa bisa bertambah. Salah satu antara lain modul PKN yang dalam penyampaian nya bisa memakai model pendidikan kooperatif jenis STAD merupakan modul Perilaku Kepahlawanan. Model pembelajaran kooperatif tipe STAD merupakan model pembelajaran dimana para siwa diberikan kesempatan bekerja dalam kelompok kecil untuk menyelesaikan suatu masalah secara bersama-sama. Maka dari itu pembalajaran PKN harus dengan baik sehingga mampu membuat siswa lebih menarik dan memotivasinya untuk belajar. Berdasarkan hal tersebut diatas, maka peneliti mencoba menyelidiki adakah pengaruh hasil belajar PKN dengan menggunakan Model Pembelajaran kooperatif tipe STAD (Student Teams Achievement Division) pada siswa Kelas IV SDN LenggahSari 04 Cabang Bungin Bekasi.

(Solihatin 2008, 4) Mengemukakan bahwa belajar koopertife adalah suatu model pembelajaran dimana siswa belajar dan bekerja dalam kelompok-kelompok kecil secara 
kolaboratif yang anggotanya terdiri dari 4-6 orang dengan struktur kelompok yang bersifat hoterogen. (Anita 2009, 189) mengemukakan bahwa belajar kooperatif seperti yang dikutip oleh Isjoni adalah sistem pembelajaran yang memberi kesempatan kepada peserta didik untuk bekerjasama dengan siswa-siswa lain dalam tugas terstruktur. Lie mengatakan bahwa pembelajaran kooperatif dikembangkan dengan dasar asumsi bahwa proses belajar akan berhasil jika peserta didik saling mengajari.

(Anita 2009,5) Model pembalajaran Koopetif tipe STAD merupakan suatu model pembelajaran yang membantu siswa mengembangkan pemahaman dan sikapya sesuai dengan kehidupan dimasyarakat, sehingga dengan bekerja bersama-sama antar angota kelompok akan meningkatkan motivasi, produktif, dan perolehan belajar. Berdasarkan pendapat di atas dalam pelaksanakan Model Pembelajaran Kooperatif Tipe STAD diperlukan kemampuan serta kreatifitas guru dalam mengelola lingkungan kelas. Sehingga dengan menggunakan model pembelajaran ini guru harus menjadi aktif terutama saat menyusun rencana pembelajaran secara matang, pengaturan kelas saat pelaksanaan, dan membuat tugas untuk dikerjakan siswa bersama- bersama dengan kelompoknya.

STAD (Student Teams Achievement Division) yakni Model pembelajaran kooperatif yang di kembangkan oleh Slavin. Ide dasar STAD ialah bagaimana memotivasi siswa untuk aktif berinteraksi saling membantu, saling memotivasi dalam memahami materi dan menyelesaikan tugas kelompok, mendorong dan membantu siswa dalam menyelesaikan latihan atau pekerjaan rumah dan membantu di kelas.

\section{Tahap - tahap STAD (Student Teams Achievement Division)}

Lima tahap yang harus di lalui dalam pembelajaran kooperatif tipe STAD (Student Teams Achievement Division) menurut Slavin seperti yang dikutip oleh Isjoni yaitu :

A. (Anita 2007, 51) Tahap penyajian materi, Guru memulai dengan menyampaikan indicator yang harus dicapai dan memotivasi rasa ingin tahu siswa tentang materi yang akan di pelajari. Teknik penyampaian materi dapat dilakukan secara klasikal maupun audio visual.

B. Tahap kegiatan kelompok, Pada tahap ini anggota kelompok diberikan tugas dan lembar kerja sebagai bahan yang akan didiskusikan dalam kelompok. Setiap anggota saling berbagi tugas, saling membantu memberikan penyelesaian agar semua anggota kelompok dapat memahami yang dibahas dan satu lembar di kumpulkan sebagai hasil kerja kelompok: 
1. Tahap tes individu, Tes individu yang digunakan untuk mengetahui sajauh mana keberhasilan belajar yang telah dicapai. Pada penelitian ini tes individual diadakan pada akhir pertemuan kedua dan ketiga. Skor perolehan individu didata dan arsipkan, yang akan digunakan pada perhitungan perolehan skor kelompok;

2. Tahap perhitungan skor perkembangan individu, pada tahap ini peneliti menghitungkan skor berdasarkan skor perolehan nilai individu, sedang pehitungan skor kelompok dilakukan dengan cara menjumlahkan masing-masing perkembangan skor individu;

3. Tahap pemberian penghargaan, Pemberian penghargaan diberikan berdasarkan perolehan skor rata-rata yang dikatagorikan menjadi kelompok terbaik, kelompok hebat dan kelompok super.

\section{Kelebihan pemebelajaran Koopetaif tipe STAD (Student Teams Achievement Division).}

(Kurniasih and Sani 2015, 22-23) Adapun kelebihan dari model pembelajaran kooperatif tipe STD yaitu : Karena dalam kelompok siswa dituntut untuk aktif sehingga dengan model ini siswa dengan sendirinya akan percaya diri dan meningkatkan kecakapan individunya. Interaksi sosial yang terbangun dalam kelompok, dengan sendirinya siswa belajar dalam bersosialisasi dengan lingkungannya (kelompok). Dengan kelompok yang ada, siswa diajarkan untuk membangun komitmen dalam mengembangkan kelompoknya.,Mengajarkan menghargai orang lain dan saling percaya.Dalam kelompok siswa diajarkan untuk saling mengerti dengan materi yang ada, sehingga siswa saling memberitahu dan mengurangi sifat kompetitif. Dari pengertian STAD (Student Teams Achievement Division) diatas maka peneliti mensintesiskan bahwa dari berbagai tahap yang harus dilalui dalam pembelajaran kooperatif: Tahap penyajian materi, tahap kegiatan kelompok, tahap tes individu, tahap penghitungan skor perkembangan individu, dan tahap pemberian penghargaan. Jadi, STAD (Student Teams Achievement Division) suatu model pembelajaran yang di dalamnya membantu siswa untuk beraktifitas dan berinteraksi serta saling bekerja sama membantu satu sama lain, baik dalam memahami materi maupun menyelesaikan tugas dalam satu kelompok, sehingga akan terjadi adanya interaksi.

\section{METODE PENELITIAN}

Penelitian ini dilaksanakan dikelas IV A dan IV B SDN Lenggahsari 04 Cabang Bungin Bekasi. Waktu penelitian dilaksanakan dari bulan Oktober - Desember 2019. Akibat 
kurangnya dana penelitian, maka penelitian dilanjutkan kembali pada April - Mei 2021. Penelitian ini menggunakan metode eksperimen. Metode penelitian eksperimen adalah metode penelitian yang digunakan untuk mencari pengaruh pelakuan tertentu terhadap yang lain dalam kondisi yang terkendalikan. Desain yang digunakan dalam penelitian ini menggunakan desain "test after randomization only" (Sugiyono 2008, 185). Kelompok pertama yang mendapatkan perlakuan berupa metode pembelajaran kooperatif STAD disebut kelas eksperimen dan kelompok kontrol. Kedua kelompok dianggap sama dalam semua aspek yang relevan dan perbedaan nya hanya pada perlakuan. Bandingan hasil pengukuran kedua kelompok variabel dependen untuk mengamati pengaruh dan studi X. Perlakuan terhadap kelas eksperimen dan kelas kontrol dapat dlihat pada table berikut.

Tabel 1. Kelas Eksperimen dan Kelas Kontrol

\begin{tabular}{|c|c|c|}
\hline $\begin{array}{c}\text { KEGIA } \\
\text { TAN }\end{array}$ & $\begin{array}{c}\text { KELAS } \\
\text { EKSPERIMEN } \\
\text { (STAD) }\end{array}$ & $\begin{array}{c}\text { KELAS } \\
\text { KONTROL } \\
\text { (Konvensional) }\end{array}$ \\
\hline $\begin{array}{l}\text { Sampaik } \\
\text { an tujuan } \\
\text { dan } \\
\text { motivasi } \\
\text { siswa }\end{array}$ & $\begin{array}{l}\text { Guru membicarakan } \\
\text { tujuan pembelajaran } \\
\text { dari kegiatan } \\
\text { pembelajaran, dan } \\
\text { tekankan pentingnya } \\
\text { teori yang akan } \\
\text { dipelajari untuk } \\
\text { merangsang belajar } \\
\text { siswa. }\end{array}$ & $\begin{array}{l}\text { Guru membicarakan } \\
\text { tujusn pembelajaran } \\
\text { dan menekankan } \\
\text { pentingnya teori } \\
\text { yang akan dipelajari } \\
\text { dan motivasi belajar } \\
\text { siswa }\end{array}$ \\
\hline $\begin{array}{l}\text { Menyiap } \\
\text { kan } \\
\text { Informas } \\
\text { i }\end{array}$ & $\begin{array}{l}\text { Guru mempersiapkan } \\
\text { setiap materi untuk } \\
\text { siswa melalui } \\
\text { presentasi atau bahan } \\
\text { bacaan }\end{array}$ & $\begin{array}{l}\text { Guru } \\
\text { mempersiapkan } \\
\text { segala informasi atau } \\
\text { bahan untuk siswa } \\
\text { menajdi beerapa } \\
\text { kepada kelompok. }\end{array}$ \\
\hline $\begin{array}{l}\text { Bagilah } \\
\text { siswa } \\
\text { menjadi }\end{array}$ & $\begin{array}{l}\text { Guru memberikan ke } \\
\text { kelompok kepada } \\
\text { siswa. Setiap }\end{array}$ & $\begin{array}{l}\text { Guru memberikan } \\
\text { kelompok ke dalam } \\
\text { kelompok terdiri dari }\end{array}$ \\
\hline
\end{tabular}




\begin{tabular}{|c|c|c|}
\hline $\begin{array}{l}\text { beberapa } \\
\text { kelompo } \\
\text { k belajar }\end{array}$ & $\begin{array}{l}\text { kelompok 4-6 orang. } \\
\text { Mereka } \\
\text { mengutamakan } \\
\text { keragaman kelas } \\
\text { dalam hal prestasi } \\
\text { akademik, jenis } \\
\text { kelamin, selera atau } \\
\text { ras. }\end{array}$ & $\begin{array}{l}\text { 4- } 6 \text { orang dan } \\
\text { meberi mereka } \\
\text { nomor }\end{array}$ \\
\hline $\begin{array}{l}\text { Bimbing } \\
\text { an setiap } \\
\text { masing - } \\
\text { masing } \\
\text { kelompo } \\
\text { k }\end{array}$ & $\begin{array}{l}\text { Siswa belajar dalam } \\
\text { kelompok yang telah } \\
\text { dibentuk LKS } \\
\text { persiapan guru } \\
\text { berfungsi sebagai } \\
\text { pedoman kerja } \\
\text { kelompok agar semua } \\
\text { anggota dapat } \\
\text { memahami dan } \\
\text { memberikan } \\
\text { kontribusi. Dalam } \\
\text { kerja tim guru } \\
\text { mengamati dan } \\
\text { memberikan } \\
\text { bimbingan, dorongan } \\
\text { dan bantuan bila } \\
\text { diperlukan. }\end{array}$ & $\begin{array}{l}\text { Guru mengajukan } \\
\text { pertanyaan kepada } \\
\text { setiap siswa dan guru } \\
\text { membimbing siswa } \\
\text { untuk berfikir dan } \\
\text { berdiskusi bersama } \\
\text { untuk menyelesaikan } \\
\text { tugasnya masing - } \\
\text { masing. Jika ada } \\
\text { yang mengalami } \\
\text { kesulitan dalam } \\
\text { mengerjakan soal } \\
\text { mereka akan } \\
\text { memberikan bantuan } \\
\text { dan membimbing } \\
\text { yang cukup }\end{array}$ \\
\hline Evaluasi & $\begin{array}{l}\text { Guru mengevaluasi } \\
\text { hasil belajar dengan } \\
\text { menguji materi yang } \\
\text { teah dipelajari dan } \\
\text { mengevaluasi kinerja } \\
\text { masing - masing } \\
\text { kelompok }\end{array}$ & $\begin{array}{l}\text { Saat mengerjakan } \\
\text { kuis, siswa tidak } \\
\text { boleh bekerjasama. } \\
\text { Guru memanggil } \\
\text { satu nomor dan } \\
\text { setiap kelompok } \\
\text { siswa dengan nomor } \\
\text { yang sama }\end{array}$ \\
\hline
\end{tabular}




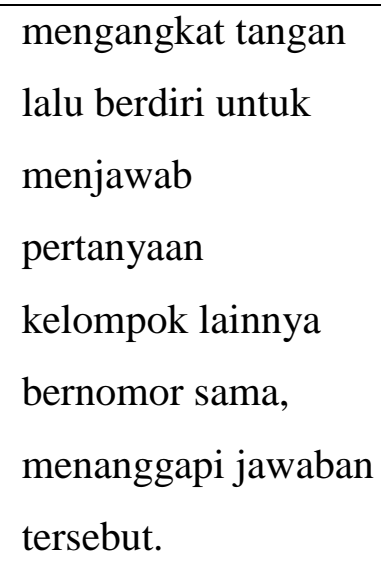

Berdasarkan persyaratan analisis data dan dalam pengujian hipotesis, maka harus dibuktikan terlebih dahulu bahwa data-data yang akan di analisis tersebut berdistribusi normal dan berasal dari varian yang homogen. Oleh kerena itu, terlebih dahulu dilakukan pengujian data agar memenuhi persyaratan analisis. Untuk menguji dalam penelitian ini adalah uji normalitas data digunakan uji Lilifors dan uji homogenitas digunakan uji F.

Uji normalitis bertujuan untuk mengetahui apakah sampel berasl dari populasi berdistribusi normal atau tidak. Uji normalitas data dilakukan terhadap data hasil belajar untuk kelompok dengan menggunakan uji Liliefors. Hal ini diharapkan bahwa sampel yang terdiri dari 72 orang siswa dan terbagi menjadi 2 kelompok apakah berdistribusi normal. Hipotesis untuk uji normalitas:

H0 : Sampel berasal dari populasi berdistribusi normal.

H1 : Sampel bukan berasal dari populasi berdistribusi normal.

Kriteria pengujian adalah jika Lhitung $<$ Ltabel dengan $\alpha=0,05$ maka H0 diterima yang berarti sampel berasal dari polulasi berdistribusi normal.

Uji ormalitas tipe STAD pada pelajaran PKN, Berdsarkan hasil perhitungan terhadap hasil kelas dengan metode Cooperative Learning tipe STAD dalam pembelajaran PKn dengan kriteria yang di gunakan pada uji normalitas adalah bahwa data empati pada kelompok dengan metode Cooperative Learning tipe STAD dalam pembelajaran PKn, berasal dari populasi yang berdistribusi normal apabila Lhitung < Ltabel. Nilai Lhitung terbesar adalah 0,114, Ltabel untuk $n=36$ dengan taraf signifikan 0,05 adalah 0,147. Dengan demikian dapat disimpulkan data empati kelas eksperimen berdistribusi normal.

Uji Normalitas tipe Konvensional pada pelajaran PKN, Berdasarkan hasil perhitungan terhadap data empati kelas dengan metode Cooperative Learning tipe Konvensional dalam pembelajaran PKn dengan kriteria yang di gunakan pada uji normalitas adalah bahwa data 
hasil belajar siswa pada kelompok dengan metode Cooperative Learning tipe Konvensional dalam pembelajaran PKn, berasal dari populasi yang berdistribusi normal apabila Lhitung < Ltabel. Nilai Lhitung terbesar adalah 0,071, Ltabel untuk $n=36$ dengan taraf signifikan 0,05 adalah 0,147. Dengan demikian dapat disimpulkan data hasil belajar kelas kontrol berdistribusi normal.

Selain uji normalitas, salah satu syarat yang harus dilakukan sebelum menguji hipotesis penelitian adalah dengan uji homogenitas. Uji homogenitas dalam penelitian ini menggunakan uji F. Uji homogenitas dilakukan untuk mengetahui apakah keseluruhan varians homogen.Kriteria pengujiannya adalah terima $\mathrm{H} 0$ yang berarti populasi mempunyai varians yang sama atau homogen, jika Fhitung $<$ Ftabel dalam taraf nyata $\alpha=0,05$. Berdasarkan perhitungan diperoleh nilai Fhitung $=0,76$, sedangkan Ftabel untuk taraf signifikansi $(\alpha) 0,05$ dengan dk (36) adalah 4,12 berarti Fhitung $(0,76)<$ Ftabel $(0,05 ; 36)$ $(4,12)$ berarti variansi dari kedua kelompok tersebut adalah homogen.

Data post-test kelas eksperimen dan kelas control berdistribusi normal dan homogeny, sehingga salah satu kelas layak untuk di uji dsn dilakukan hipotesis dengan uji-t. Pengujian Hipotesis dilakukan untuk mengetahui apakah hipotesis yang diajukan ditolak dan terima. Sebelumnya dilakukan uji hipotesis, terlebih dahulu dilakukan pengujian persyaratan analisis yang meliputi uji normalitas dan uji homogenitas data hasil belajar pada kelas eksperimen maupun kelas kontrol. Berdasarkan hasil perhitungan pada pengujian tersebut, diketahui bahwa kedua kelompok data tersebut berdistribusi normal dan memiliki varian yang homogen sehingga meliputi syarat untuk melakukan pengujian hipotesis dengan menggunakan uji-t.

Berdasarkan hasil perhitungan pada taraf signitif $\alpha=0,05$, didapat thitung $=2,673$ dan ttabel $=2,03$. Dengan demikian thitung $>$ ttable sehingga H0 ditola, dapat disimpulkan bahwa terdapat perbedaan hasil belajar antara dengan metode kooperatif tipe STAD (Student Teams Achievement Division) dalam pembelajaran PKn dan hasil belajar dengan metode kooperatif tipe Konvensiaonal dalam pembelajaran PKn dapat di terima.

\section{HASIL DAN PEMBAHASAN}

Berdasarkan hasil penelitian dan perhitungan secara stastistik dengan menggunakan uji-t pada $\alpha$ $=0,05$ diperoleh harga $t_{\text {hitung }}$ sebesar 2,673 lebih besar daripada $t_{\text {tabel }} 2,03$. Hal ini menunjukkan bahwa hipotesis nol ditolak sehingga $\mathrm{H} 1$ diterima, itu artinya terdapat pengaruh metode kooperatif tipe STAD (Student Teams Achievement Division) dalam pembelajaran PKn terhadap hasil belajar 
kelas IV SDN Lenggahsari 04 Cabang Bungin Bekasi. Pengaruh tersebut dapat dilihat dari nilai rata-rata yang diperoleh oleh kedua kelompok siswa IV. Rata-rata skor hasil belajar siswa kelas IV dengan metode kooperatif tipe STAD (Student Teams Achievement Division) dalam pembelajaran PKn adalah 66,08 sedangkan skor hasil belajar siswa kelas IV dengan menggunakan metode kooperatif tipe Konvensional dalam pembelajaran PKn adalah 63,5.

Perbedaan rata-rata tersebut pada kedua kelas karena pada metode kooperatif tipe STAD (Student Teams Achievement Division) dalam pembelajaran PKn setiap siswa memiliki kesempatan untuk memberikan kontribusi yang substansial kepada kelompoknya, dan posisi anggota kelompok adalah setara. Menggalakkan interaksi secara aktif dan positif dan kerjasama anggota kelompok menjadi lebih baik.

Metode ini merupakan metode pembelajaran yang Membantu siswa untuk memperoleh hubungan pertemanan lintas rasial yang lebih banyak, sehingga pembelajaran melalui metode ini melatih siswa dalam mengembangkan aspek kecakapan sosial di samping kecakapan kognitif, metode ini menjadikan peran guru juga menjadi lebih aktif dan lebih terfokus sebagai fasilitator, mediator, motivator dan evaluator.

Dapat dikemukan di atas bahwa penggunaan metode STAD (Student Teams Achievement Division) dalam pembelajaran PKn pada kegiatan pembelajaran berpengaruh terhadap hasil belajar siswa kelas IV. Khususnya pada kelas IV A yaitu kelas eksperimen. Hal ini terbukti bahwa skor rata-rata siswa lebih tinggi di kelas eksperimen dibanding kelas kontrol.

\section{KESIMPULAN}

Berdasarkan pembahasan hasil penelitian, dapat disimpulkan bahwa antara metode STAD dan kooperatif konvensional pembelajaran PKN akan berdampak pada kinerja siswa kelas IV SD. Penggunaan metode kooperatif tradisional. Hal ini sejalan dengan hipotesis penelitian yang terlihat dari hasil $\mathrm{t}=2.673>2.03011=\mathrm{t}$ table yang berartid Ho ditolak dan $\mathrm{H} 1$ diterima.

Dengan melihat metode kerja sama STAD dalam pembelajaran PKN, nilai rata - rata prestasi akademik siswa adalah 66,08. Metode kerja sama STAD berdampak pada hasil belajar siswa SD IV dalam pembelajaran PKN. Metode kerja sama dalam pembelajaran PKN ditunjukan sebagai berikut: 63,5, jadi siswa skor hasil belajar siswa berbeda dengan 2,58.

\section{Implikasi.}

Atas dasar penelitian teoritis dan mengacu pada hasil penelitian ini, penelitian ini 
memberikan beberapa wawasan untuk meningkatkan hasil belajar siswa yaitu: (1) Metode pembelajaran ini menggunakan kolaborasi STAD dan metode kolaborasi konvensional dalam pembelajaran PKN. Guru dapat mempertimbangkan kedua metode pembelajaran ini ketika sedang dalam proses pembelajaran. Karena dalam penelitian ini telah dibuktikan bahwa penerapan metode pembelajaran dapat meningkatkan hasil belajar siswa khususnya pada mata pelajaran PKN. (2) Metode kolaborasi STAD dalam pembelajaran PKN dirancang sedemikian rupa sehingga perlu diciptakan suasana yang menarik dengan mengajukan topik-topik yang menantang berkesan dan kreatif. (3) Dalam pembelajaran koopertif, pengetahuan tidak hanya dapat diperoleh dengan membaca buku, tetapi juga dengan bertukar pendapat tentang segala hal yang berkaitan dengan masalah yang dihadapi, sehingga pengetahuan siswa dapat meningkat dengan terdapatnya masukan dari sahabatsahabat dalam pembelajaran. Kelompok riset ini meyakinkan kalo dengan memakai tata cara pendidikan yang pas serta memohon belajar siswa. Dampak belajar siswa bisa ditingkatkan, dalam penelitian ini pula sudah dibuktikan kalau tata cara kooperatif STAD dalam pendidikan PKN lebih efesien tingkatkan hasil belajar siswa dibandingkan tata cara pendidikan konvensional pada pendidikan PKN.

\section{DAFTAR PUSTAKA}

Anita, Lie. 2007. Mempraktekan Cooperative Learning di ruang kelas. Jakarta: PT. Grasindo.

Agustino, R., \& Pertiwi, S. (2020). Estimation of the Relationship Between Learning Anita, Lie. 2009. Strategi Pembelajaran Inovatif Kontemporer. Jakarta: Bumi Aksara. Agustino, R., \& Pertiwi, S. (2020). Membangun Sistem Model Learning Style Inventory Untuk Pencapaian Prestasi Belajar Mahasiswa Program E-Learning. Jurnal Inovasi Pendidikan MH Thamrin, 4(2), 1-12.

Dapatermen Pendidikan Nasional. 2000. Kamus Besar Bahasa Indonesia KBBI. Balai Pustaka: Rineka Cipta.

Kurniasih at al. 2015. Ragam Pengembangan Model Pembelajaran. Kata Pena.

Solihatin, Etin. 2008. Cooperative Learning Model Pembelajaran. Jakarta: Bumi Aksara

Styles Inventory and Online Learning During the Pandemic. In Conference Series (Vol. 3, No. 1, pp. 553-561).

Sugiyono. 2008. Metode Pembelajaran Pendidikan. Bandung.

Susanto, Ahmad. 2013. Teori dan Pembelajaran. Jakarta: Prenada Media. 